\title{
Antibiotic resistance profile of Staphylococcus aureus clinical isolates from Nigeria
}

\author{
OO Ayepola*, L Egwari, Gl Olasehinde \\ From 3rd International Conference on Prevention and Infection Control (ICPIC 2015) \\ Geneva, Switzerland. 16-19 June 2015
}

\section{Introduction}

Hospital-acquired infections with Staphylococcus aureus have increased over the years and the rise in incidence has been accompanied by a rise in antibiotic-resistant strains notably methicillin-resistant $S$. aureus (MRSA) and more recently vancomycin-resistant strains. In order to have adequate information for treatment of infections caused by $S$. aureus, it is important to understand trends in the antibiotic-resistance patterns as well as diversity of strains across geographical regions.

\section{Objectives}

The aim of this study was to provide information on the antibiotic resistance profile and molecular characteristics of $S$. aureus strains from Nigeria.

\section{Methods}

A total of 209 non-duplicate $S$. aureus isolates obtained from clinical infections in eight medical centres were analyzed. Identification and antimicrobial susceptibility profile was performed with the automated VITEK-2 system. Detection of antibiotic resistance and virulence genes in the $S$. aureus strains was by polymerase chain reaction.

\section{Results}

Resistance was observed against penicillin (97.1\%); trimethoprim/sulfamethoxazole (83.7\%), tetracycline (13.8\%), levofloxacin $(5.7 \%)$ and gentamicin(4.8\%). All strains were susceptible to azithromycin, clarithromycin, erythromycin, clindamycin, linezolid, vancomycin, nitrofurantoin, fusidic acid, mupirocin and rifampicin. The $\beta$-lactamase (blaZ) gene was found in $95 \%$ of allstrains $(n=198)$ while $2.87 \%$ $(\mathrm{n}=6)$ possessed the mecA gene. The staphylococcal cassette chromosome mec (SCC mec) typing of MRSA strains detected SCC mec type IV in one strain. A particular

Biological Sciences, Covenant University, Ota, Nigeria
MRSA strain was the only strain found to be resistant to teicoplanin, tigecycline and fosfomycin. Fifty-six percent of the strains possessed the panton valentine leukocidin (PVL) encoding gene.

\section{Conclusion}

A rise in PVL-positive S. aureus strains in Africa is of great concern as this could promote the emergence of highly virulent strains. The continuous surveillance of antibiotic resistance in $S$. aureus is important to prevent the spread of multidrug resistant strains.

\section{Disclosure of interest}

None declared.

Published: 16 June 2015

doi:10.1186/2047-2994-4-S1-P195

Cite this article as: Ayepola et al:: Antibiotic resistance profile of Staphylococcus aureus clinical isolates from Nigeria. Antimicrobial Resistance and Infection Control 2015 4(Suppl 1):P195.

Submit your next manuscript to BioMed Central and take full advantage of:

- Convenient online submission

- Thorough peer review

- No space constraints or color figure charges

- Immediate publication on acceptance

- Inclusion in PubMed, CAS, Scopus and Google Scholar

- Research which is freely available for redistribution 